\title{
Gender difference in anaerobic capacity: role of aerobic contribution
}

\author{
David W. Hill PhD and Jimmy C. Smith PhD \\ Department of Kinesiology, University of North Texas, Denton, Texas, USA
}

\begin{abstract}
The purpose of this study was to evaluate effects of gender on anaerobic and aerobic contributions to high-intensity exercise. A group of 38 subjects (22 women, 16 men) performed modified Wingate tests against resistances of $0.086 \mathrm{~kg} \mathrm{~kg}^{-1}$ body mass $\left(0.844 \mathrm{~N} \mathrm{~kg}^{-1}\right)$ for women and $0.095 \mathrm{~kg} \mathrm{~kg}^{-1}$ body mass $\left(0.932 \mathrm{~N} \mathrm{~kg}^{-1}\right)$ for men. The aerobic contribution to total work performed was determined from breath-by-breath analyses of expired gases during each test. Total work in $30 \mathrm{~s}$ was $30 \%$ lower (Student's $t$ test; $P<0.01)$ in women than men $(211 \pm$ $5 \mathrm{~J} \mathrm{~kg}^{-1}$ versus $\left.299 \pm 14 \mathrm{~J} \mathrm{~kg}^{-1}\right)$. Aerobic contribution was only $7 \%$ lower $(P=0.12)$ in women than men $(53 \pm$ $1 \mathrm{~J} \mathrm{~kg}^{-1}$ versus $\left.57 \pm 2 \mathrm{~J} \mathrm{~kg}^{-1}\right)$. The anaerobic component of the work performed, determined by subtraction of the aerobic component from total work in $30 \mathrm{~s}$, was $35 \%$ lower $(P<0.01)$ in women than men $\left(158 \pm 5 \mathrm{~J} \mathrm{~kg}^{-1}\right.$ versus $242 \pm$ $15 \mathrm{~J} \mathrm{~kg}^{-1}$ ). It is concluded that, because women provide a relatively higher $(P<0.01)$ portion of the energy for a 30 -s test aerobically than men $(25 \%$ versus $20 \%)$, total work during a Wingate test actually underestimates the gender difference in anaerobic capacity between women and men.
\end{abstract}

Keywords: Anaerobic power, anaerobic capacity, aerobic metabolism, men, women, gender differences, sex differences

The Wingate power test ${ }^{1,2}$ is one example of a test that has been designed to estimate anaerobic power and capacity during cycling exercise. Men and women show consistent differences in absolute and mass-corrected estimates of anaerobic power and capacity $^{3-6}$.

It is clear that even during short-term highintensity exercise, some adenosine $5^{\prime}$-triphosphate (ATP) regeneration occurs via oxidative phosphorylation $^{1,7-12}$. The magnitude of aerobic contribution to all-out efforts of about 30-s duration has recently been estimated to be 9 to $19 \%^{8}, 28 \%^{10}$, or as high as $40 \%{ }^{11}$.

There are differences between men and women in absolute and mass-corrected estimates of maximal aerobic power ${ }^{13}$ as well as in anaerobic power and capacity $^{3-6}$. All recent studies of the interplay between aerobic and anaerobic energy sources during Wingate tests, or other tests involving short-term high power outputs, have used male subjects ${ }^{8-11}$.

Address for correspondence: David W. Hill PhD, Department of Kinesiology, PO Box 13857, University of North Texas, Denton, Texas 76203-3857, USA

(C) 1993 Butterworth-Heinemann Ltd 0306-3674/93/010045-04
The purpose of this study was to evaluate effects of gender on the aerobic and anaerobic contributions to performance during a modified Wingate power test. These comparisons will provide insight into some factors related to the gender difference in measures of anaerobic capacity.

\section{Subjects and methods}

A total of 92 modified Wingate power tests was performed by 38 healthy college students. Subjects performed up to five tests, each on a different day. Data from some tests were lost because of technical problems; complete results were available from between two and five tests per person. Each individual's results were averaged in order that each subject contributed only one data point to the statistical analyses. The 22 women had a mean(s.d.) age of $22(4)$ years, height $168(7) \mathrm{cm}$, and mass $58.2(7.7) \mathrm{kg}$; the 16 men had a mean age of $23(2)$ years, height $180(9) \mathrm{cm}$, and mass $82.1(16.1) \mathrm{kg}$. The subjects were physical education majors who ranged in fitness level. There were several men and women who were quite sedentary and also several men and women who were apparently fit. None of the subjects was in training for a competitive sport at the time of the study.

\section{Modified Wingate tests - selection of resistance}

Tests were performed on a basket-loaded Monark 864 ergometer, with a resistance of $0.086 \mathrm{~kg} \mathrm{~kg}^{-1}$ body mass $\left(0.844 \mathrm{~N} \mathrm{~kg}^{-1}\right)$ for women and $0.095 \mathrm{~kg} \mathrm{~kg}^{-1}$ body mass $\left(0.932 \mathrm{~N} \mathrm{~kg}^{-1}\right)$ for men'.

Fair comparison of men's and women's performances requires optimal resistance settings for each gender. Resistances that are well above the original $0.075 \mathrm{~kg} \mathrm{~kg}^{-1}$ body mass ${ }^{1}$ elicit higher values for work output or mean power output in 30-s tests $2,5,14-16$, and the resistances selected for this study have been suggested as optimal settings for men and women, respectively ${ }^{12}$.

\section{Modified Wingate tests - test administration}

Subjects performed a 6-min warm-up on the cycle ergometer, at a work rate of about $90 \mathrm{~W}$ for men or $60 \mathrm{~W}$ for women, and then rested, seated, on the ergometer for $5 \mathrm{~min}$. They were then directed by standardized instructions: $10 \mathrm{~s}$ before the start of the 
test, they began unloaded pedalling; $4 \mathrm{~s}$ before the start of the test, they accelerated maximally; at ' $0 s^{\prime}$, the resistance was applied, and the test began.

During the 30-s test, pedal revolutions were mechanically determined using a read switch and magnet attached to the pedal crank. Revolutions were recorded for each 5-s period during the test.

Peak power, or anaerobic power, was the highest power produced in a 5-s segment of the test, and was expressed in $W$ and in $\mathrm{W} \mathrm{kg}^{-1}$. The traditional measure of anaerobic capacity, the total external work performed in the 30-s test, was expressed in $\mathrm{kJ}$ and in $\mathrm{Jkg}^{-1}$.

\section{Determination of aerobic versus anaerobic contribution}

$\dot{V}_{\mathrm{O}_{2}}$ during the tests was determined on a breath-bybreath basis using a SensorMedics 4400tc metabolic cart (SensorMedics, Anaheim, California, USA). The SensorMedics system incorporates fast-responding gas analysers, a turbine flowmeter, and computer correction to account for the time difference in responses of the flowmeter and the gas analysers.

Aerobic contribution was calculated based on the $\dot{V}_{\mathrm{O}_{2}}$ that was measured during the test, and then converted to work units with a factor of $20.92 \mathrm{~kJ} \mathrm{IO}_{2}^{-1}$. The following assumptions were made:

1. Muscular (gross) efficiency was $22 \%$;

2. There was a time delay of approximately 10-15 s between increased $\dot{V}_{2}$ at the muscle and increased $\dot{V}_{2}$ at the mouth ${ }^{17}$, and the initial increase in $\dot{V}_{2}$ at the mouth reflected a 'cardiodynamic effect $^{18}$;

3. $\mathrm{O}_{2}$ stores of about $2.3 \mathrm{ml} \mathrm{kg}^{-1}$ body mass ${ }^{19}$ were used at the onset of exercise.

Stainsby et al. ${ }^{20}$ and Cavanagh and $\mathrm{Kram}^{21}$ have argued in favour of the use of muscular rather than net efficiency measures. In the present study, a $22 \%$ muscular efficiency was used in calculations ${ }^{22}$. This has been suggested as appropriate for both aerobic and anaerobic exercise 22 . We are not aware of any reports of gender differences in efficiency. We have compared efficiency of men and women performing cycling exercise at between $55 \%$ and $65 \%$ of $\dot{V}_{\mathrm{O}_{2} \max }$ and found no difference $\left(t_{12}=0.37, P=0.72\right)$ in efficiency (unpublished).

The time delay of $\approx 10-15 \mathrm{~s}$ between increased $\mathrm{VO}_{2}$ at the muscle and increased $V \mathrm{O}_{2}$ at the mouth ${ }^{17}$ and the initial increase in $\mathrm{VO}_{2}$ at the mouth reflects a 'cardiodynamic effect' ${ }^{\prime 18}$. Therefore, aerobic contribution for the 0 - to 10 -s time period was calculated by back-extrapolation from the $\mathrm{VO}_{2}$ measured during the 10 - to 15 -s period in the test ${ }^{10}$. Aerobic contribution for the 10- to 30-s time period is based directly on $\mathrm{VO}_{2}$ measured during that time.

Previous estimates of the magnitude of the $\mathrm{O}_{2}$ stores have varied. Barstow et al. ${ }^{19}$ have reported values equivalent to $2.3 \mathrm{ml} \mathrm{kg}^{-1}$ body mass; Medbø and Tabata ${ }^{9}$ used a value of $5.6 \mathrm{ml} \mathrm{kg}^{-1}$ body mass in one study and Medbø et al. ${ }^{23}$ used $6.0 \mathrm{ml} \mathrm{kg}^{-1}$ body mass in another; DIPrampero et al. ${ }^{24}$ have estimated that the stores are as high as $6.4 \mathrm{ml} \mathrm{kg}^{-1}$ body mass.
Inman et al. ${ }^{25}$ reported depletion of $139 \mathrm{ml}$ from $\mathrm{O}_{2}$ stores during the transition from rest to submaximal exercise $(100 \mathrm{~W})$ - this was equivalent to $2.1 \mathrm{ml} \mathrm{kg}^{-1}$ body mass. We have selected the theoretical value of $2.3 \mathrm{ml} \mathrm{kg}^{-1}$ body mass proposed by Barstow et al. ${ }^{19}$ as it most closely approximated the value actually measured by Inman et al. ${ }^{25}$ We are not aware of any reports of gender differences in the size of the $\mathrm{O}_{2}$ stores. The magnitude of the stores is estimated as a function of body mass, and this should account for the differences in body size between the sexes.

\section{Data analyses}

Aerobic contribution was expressed in terms of absolute power output (W), power output relative to body mass $\left(\mathrm{W} \mathrm{kg}^{-1}\right)$, or aerobic work performed as a percentage of the total work performed. Anaerobic contribution was calculated based on differences between total measured power or work and the estimated aerobic contributions. Total work in $30 \mathrm{~s}$ has traditionally been termed the anaerobic capacity. In this paper, total work is separated into its aerobic and anaerobic components.

Gender differences were evaluated statistically using $t$ tests for independent means. Values are expressed as means(s.e.).

\section{Results}

Peak power, which always occurred during the first 5-s segment of the exercise test, was 595(18) W $\left(10.2(0.2) \mathrm{W} \mathrm{kg}^{-1}\right)$ for the women and 1099(76) W (13.3(0.4) $\mathrm{W} \mathrm{kg}^{-1}$ ) for the men. Relative to body mass, the women's mean peak power was $77 \%$ of the men's $(P<0.01)$.

Over the course of the test, power output declined $50(1) \%$ in the women and $45(3) \%$ in the men. This power decline, or fatigue index, was the same $(P=$ 0.10 ) in the women and men.

Mean values for total work in $30 \mathrm{~s}$, and the aerobic and anaerobic portions of that work, are presented in Table 1. Women performed $49 \%$ as much work as men in the $30 \mathrm{~s}(P<0.01)$, about $45 \%$ as much anaerobic work $(P<0.01)$, and about $67 \%$ as much aerobic work $(P<0.01)$. When measures were corrected for body mass, the gender differences were reduced: women performed $71 \%$ as much total work $(P<0.01)$, about $65 \%$ as much anaerobic work $(P<$ $0.01)$, and about $93 \%$ as much aerobic work $(P=$ 0.12 ). Over the 30 -s test, women performed a greater

Table 1. Mean(s.e.) absolute and mass-corrected total work, aerobic work, and anaerobic work $\left(\mathrm{kJ}, \mathrm{J} \mathrm{kg}^{-1}\right)$ for men and women

\begin{tabular}{|c|c|c|c|}
\hline & Total work & Anaerobic work & Aerobic work \\
\hline Men & $25.0(2.3) \mathrm{kJ}$ & $20.3(2.1) \mathrm{kJ}$ & $4.6(0.2) \mathrm{kJ}$ \\
\hline Women & $12.3(0.3) \mathrm{kJ}$ & 9.2(0.4) kJ & $3.1(0.1) \mathrm{kJ}$ \\
\hline Difference & $51 \%, P<0.01$ & $55 \%, P<0.01$ & $34 \%, P<0.01$ \\
\hline Men & $299(14) \mathrm{Jkg}^{-1}$ & $242(15) \mathrm{J} \mathrm{kg}^{-1}$ & $57(2) \mathrm{Jkg}^{-1}$ \\
\hline Women & $211(5) \mathrm{Jkg}^{-1}$ & $158(5) \mathrm{J} \mathrm{kg}^{-1}$ & $53(1) \mathrm{J} \mathrm{kg}^{-1}$ \\
\hline Difference & $30 \%, P<0.01$ & $35 \%, P<0.01$ & $7 \%, P=0.12$ \\
\hline
\end{tabular}

Difference scores are calculated as (men - women)/men $\times 100$ 
proportion $(P<0.01)$ of the total work aerobically than did men $(25(1) \%$ versus $20(1) \%)(P<0.01)$.

Aerobic metabolism gradually increased throughout the test. The aerobic power output peaked at 137(5) W (2.4(0.1) $\left.\mathrm{W} \mathrm{kg}^{-1}\right)$ for women and 199(8) W (2.5(0.1) $\left.\mathrm{W} \mathrm{kg}^{-1}\right)$ for men. During the last $5 \mathrm{~s}$ of the test, aerobic mechanisms were responsible for $47(1) \%$ of the power output for the women and $36(3) \%$ of the power output for men.

\section{Discussion}

\section{Peak power and anaerobic capacity}

Peak power values in this study are similar to values that have been reported elsewhere ${ }^{4,26}$. Our women's and men's peak powers were 10.2 and $13.3 \mathrm{~W} \mathrm{~kg}^{-1}$. Our women's means were $17 \%$ higher than the $8.7 \mathrm{~W} \mathrm{~kg}^{-1}$ reported for the female physical education students of Serresse et al. ${ }^{6}$, but within the range of 9.1 to $11.1 \mathrm{~W} \mathrm{~kg}^{-1}$ reported by Shaw et al. ${ }^{15}$ for women softball players. Our men's means were $11 \%$ higher than the $12.0 \mathrm{~W} \mathrm{~kg}^{-1}$ reported for the male physical education students of Serresse et al. ${ }^{6}$, but within the range of 13.2 to $14.7 \mathrm{~W} \mathrm{~kg}^{-1}$ reported by Davy et al. ${ }^{27}$ for 12 'conditioned athletes', and similar to the $12.7 \mathrm{~W} \mathrm{~kg}^{-1}$ of the untrained men of Beld et al. ${ }^{28}$

The mean amount of work performed by the women in the 30 -s test $\left(211(5) \mathrm{J} \mathrm{kg}^{-1}\right)$ was similar to the mean of 217 (no s.e. provided) from 25 women that was reported by Nebelsick-Gullett et al. ${ }^{29}$; and the men's mean (299(14) $\mathrm{J} \mathrm{kg}^{-1}$ ) is similar to the value of $294(8) \mathrm{J} \mathrm{kg}^{-1}$ reported by Vandewalle et al. ${ }^{30}$

By the very nature of this paper, it is acknowledged that the terms peak anaerobic power and anaerobic capacity are misnomers, and that reported values quantify power output or work performed that is not all derived from anaerobic sources. Thus, we have chosen to refer to the total work performed in $30 \mathrm{~s}$ as such, and not as anaerobic capacity. Moreover, it is acknowledged that a 30-s test is not long enough to exhaust the glycolytic system.

\section{Gender differences in total work performed in $30 \mathrm{~s}$}

The 30-s work output of men and women has been compared in two recent studies ${ }^{4,5}$. Murphy et al. ${ }^{5}$ used $0.075 \mathrm{~kg} \mathrm{~kg}^{-1}$ body mass $\left(0.736 \mathrm{~N} \mathrm{~kg}^{-1}\right)$ for both the men and women; they reported women's 30-s work capacity relative to body mass to be $78 \%$ that of men. Froese and Houston ${ }^{4}$ used the method of Evans and Quinney ${ }^{3}$ to determine resistance settings based on mass and thigh volume; these were $0.100 \mathrm{~kg} \mathrm{~kg}^{-1}$ body mass $\left(0.981 \mathrm{~N} \mathrm{~kg}^{-1}\right)$ for the men and $0.098 \mathrm{~kg} \mathrm{~kg}^{-1}$ body mass $\left(0.961 \mathrm{~N} \mathrm{~kg}^{-1}\right)$ for the women. They reported that women had relative 30-s work capacities of about $85 \%$ those of men, but commented that the load of $0.098 \mathrm{~kg} \mathrm{~kg}^{-1}$ $\left(0.961 \mathrm{~N} \mathrm{~kg}^{-1}\right)$ was too high for the women in their study. Serresse et al. ${ }^{6}$ reported that women's 10-s capacity was about $72 \%$ of men's, and 90 -s capacity was about $77 \%$ of men's - a resistance of $0.09 \mathrm{~kg} \mathrm{~kg}^{-1}$ body mass $\left(0.883 \mathrm{~N} \mathrm{~kg}^{-1}\right)$ was used for both women and men in the 10 -s test, and a resistance of
$0.05 \mathrm{~kg} \mathrm{~kg}^{-1}\left(0.491 \mathrm{~N} \mathrm{~kg}^{-1}\right)$ was used for both men and women in the 90 -s test.

We report a gender difference in 30-s work capacities similar to that of Serresse et al. ${ }^{6}$; compared with the men, on a per-kilogramme basis, women performed only $71 \%$ as much total work.

\section{Gender differences in aerobic and anaerobic contributions}

In this study, women performed $30 \%$ less work in $30 \mathrm{~s}$ than did the men $-211(5) \mathrm{J} \mathrm{kg}^{-1}$ compared with $299(14) \mathrm{J} \mathrm{kg}^{-1}$. Comparison with the results of Murphy et al. ${ }^{5}$ suggests that further correction for differences in body composition was not likely to narrow this difference to even within $20 \%$. This suggests that, on a per-kilogramme basis, women have an anaerobic capacity - specifically, that is a 30-s work capacity - of about $71 \%$ that of men.

Despite the relatively large difference in total work performed during the 30-s test, women and men had similar aerobic contributions. Work attributable to aerobic mechanisms was $53(1) \mathrm{J} \mathrm{kg}^{-1}$ for the women and $57(2) \mathrm{J} \mathrm{kg}^{-1}$ for men. These values differed by only $7 \%(P=0.12)$. This is not surprising, considering that the gender difference in $\mathrm{VO}_{2}$ max would be expected to be less than $20 \%$ in this population ${ }^{13}$. The difference between actual anaerobic contribution during a 30 -s bout of exercise (i.e. total work minus aerobic work) was larger than the $30 \%$ difference between the total work performed by men and women.

The traditional measure of 'anaerobic capacity', using total work in $30 \mathrm{~s}$, may actually underestimate the real gender difference in anaerobic capacity. In fact, the gender difference was $35 \%$, not $30 \%$ women were able to produce $158(5) \mathrm{J} \mathrm{kg}^{-1}$ anaerobically, which is only $65 \%$, not $71 \%$, of the $242(15) \mathrm{J} \mathrm{kg}^{-1}$ produced by the men.

Indeed, the actual gender difference in anaerobic capacity may be even greater than this $35 \%$ value. Anaerobic capacity is not exhausted in $30 \mathrm{~s}^{1,10,21,23}$. In the final $5 \mathrm{~s}$ of the test, men's anaerobic energy production was almost twice that of the women's (4.8 versus $2.7 \mathrm{~W} \mathrm{~kg}^{-1}$ ) suggesting that the men had a larger anaerobic reserve still untapped. This possibility is supported by the fact that there was a greater $(P=0.02)$ decline in power output, that is, a larger fatigue index, in the women $(50(1) \%$ ) than in the men $(44(2) \%)$. Thus, while we report a difference of $35 \%$ in anaerobic work capacity in $30 \mathrm{~s}$, we suggest that over a longer test (i.e. to exhaustion of the glycolytic mechanisms) the difference might be even greater. A larger difference would be compatible with the finding that maximal blood lactate levels in women are only slightly more than half those of men $^{31}$.

The gender differences in aerobic/anaerobic contribution may in part reflect a training effect or cultural bias. However, there was a wide range of fitness levels, as evidenced by achieved $\dot{V}_{\mathrm{O}_{2}}$ during the tests, and there was no evidence of a trend for either the men or women to be relatively more fit or trained.

Further studies comparing the aerobic and anaerobic contributions to short-term exercise by men and 
women against a variety of relative resistances may explain the relationships between resistance and 30-s work capacity, aerobic contribution, and anaerobic contribution more fully - and the role of gender in modifying these relationships.

\section{Summary of findings}

We have compared the work capacity of men and women using a modified Wingate power test with resistances determined based on gender and mass. Our results suggest that during the 30-s test, a significant portion of the total ATP regeneration is via aerobic mechanisms; this aerobic contribution is greater in women than in men when expressed as a percentage of total work accomplished, but is quite similar in women and men when expressed relative to body mass.

Total work performed in $30 \mathrm{~s}$ was $30 \%$ lower in women than in men, when results were reported on a per-kilogramme basis. Anaerobic work over the $30 \mathrm{~s}$ was $35 \%$ lower in women than in men. Therefore, we conclude that use of total work in $30 \mathrm{~s}$ as a measure of anaerobic capacity of men and women may actually underestimate the gender difference in the anaerobic capacity, because women make a relatively larger aerobic contribution during short-term exercise than do men, at least when exercising maximally for $30 \mathrm{~s}$ against the resistances provided in this study.

\section{References}

1 Bar-Or O. The Wingate anaerobic test: an update on methodology, reliability, and validity. Sports Med 1987; 4: 381-94.

2 Bar-Or O, Dotan R, Inbar O. A 30 second all-out ergometric test - its reliability and validity for anaerobic capacity. Isr J Med Sci 1977; 13: 126.

3 Evans JA, Quinney HA. Determination of resistance settings for anaerobic power testing. Can J Appl Sport Sci 1981; 6: 53-6.

4 Froese EA, Houston ME. Performance during the Wingate anaerobic test and muscle morphology in males and females. Int J Sports Med 1987; 8: 35-9.

5 Murphy MM, Patton JF, Frederick FA. Comparative anaerobic power of men and women. Aviat Space Environ Med 1986; 57: $636-41$.

6 Serresse O, Ama PFM, Simoneau J-A, Lortie G, Bouchard C, Boulay MR. Anaerobic performances of sedentary and trained subjects. Can J Sport Sci 1989; 14: 46-52.

7 Hill DW, Smith JC. Contribution of energy systems during a Wingate power test. $\mathrm{Br} J$ Sports Med 1991; 25: 196-9.

8 Kavanagh MF, Jacobs I. Breath-by-breath oxygen consumption during performance of the Wingate Test. Can J Sport Sci 1988; 13: 91-3.

9 Medbø JI, Tabata I. Relative importance of aerobic and anaerobic energy release during short-lasting exhausting bicycle exercise. J Appl Physiol 1989; 67: 1881-6.
10 Serresse O, Lortie G, Bouchard C, Boulay MR. Estimation of the contribution of the various energy systems during maximal work of short duration. Int J Sports Med 1988; 9: 456-60.

11 Stevens GHJ, Wilson BW, Raven PB. Aerobic contribution to the Wingate test. Med Sci Sports Exerc 1986; 18(Suppl): 2.

12 Vandewalle H, Kapitaniak B, Grün S, Raveneau S, Monod H. Comparison between a 30-s all-out test and a time-work test on a cycle ergometer. Eur J Appl Physiol 1989; 58: 375-81.

13 McArdle WD, Katch FI, Katch VL. Exercise Physiology: Energy, Nutrition, and Human Performance, 3rd ed. Philadelphia Pennsylvania, USA: Lea and Febiger, 1991; 205-18.

14 Lopato M, Montgomery D. The effect of body mass on power output in the Wingate test. Can J Sport Sci 1989; 14: 123P.

15 Shaw K, Davy K, Coleman C, Kamimukai C. Optimal resistance loading of the Wingate power test in female softball players. Med Sci Sports Exerc 1988; 20(Suppl): 18.

16 Sposa E, Perez HR, Wygand JW, Moruzzi R. Optimal resistance loading of Wingate power testing in soccer players. Med Sci Sports Exerc 1987; 19(Suppl): 73.

17 Hughson RL, Sherrill DL, Swanson GD. Kinetics of $\dot{V}_{\mathrm{O}_{2}}$ with impulse and step exercise in humans. J Appl Physiol 1988; 64: 451-9.

18 Whipp BJ, Ward SA, Lamarra N, Davis JA, Wasserman K. Parameters of ventilatory and gas exchange dynamics during exercise. J Appl Physiol 1982; 52: 1506-13.

19 Barstow TJ, Lamarra N, Whipp BJ. Modulation of muscle and pulmonary $\mathrm{O}_{2}$ uptakes by circulatory dynamics during exercise. J Appl Physiol 1990; 68: 979-89.

20 Stainsby WN, Gladden LB, Barclay JK, Wilson BA. Exercise efficiency: validity of base-line subtractions. I Appl Physiol: Respirat Environ Exerc Physiol 1980; 48: 518-22.

21 Cavanagh PR, Kram R. The efficiency of human movement a statement of the problem. Med Sci Sports Exerc 1985; 17: 304-8.

22 Davies CTM, Sandstrom ER. Maximal mechanical power output and capacity of cyclists and young adults. Eur J Appl Physiol 1989; 58: 838-44.

23 Medbø JI, Mohn A-C, Tabata I, Bahr R, Vaage O, Sejersted OM. Anaerobic capacity determined by maximal accumulated $\mathrm{O}_{2}$ deficit. J Appl Physiol 1988; 64: 50-60.

24 DIPrampero PE, Boutellier U, Pietsch P. Oxygen deficit and stores at onset of muscular exercise in humans. J Appl Physiol: Respir Environ Exerc Physiol 1983; 55: 146-53.

25 Inman MD, Hughson RL, Weisiger KH, Swanson GD. Estimate of mean tissue $\mathrm{O}_{2}$ consumption at onset of exercise in males. J Appl Physiol 1987; 63: 1578-85.

26 Maud PJ, Shultz BB. Norms for the Wingate Anaerobic Test with comparison to another similar test. Res $Q$ Exerc Sport 1989; 60: 144-51.

27 Davy K, Pizza F, Guastella P, McGuire J, Wygand J. Optimal loading of Wingate power testing in conditioned athletes. Med Sci Sports Exerc 1989; 21(Suppl): 27.

28 Beld K, Skinner JS, Vu Tran Z. Load optimization for peak and mean power output on the Wingate anaerobic test. Med Sci Sports Exerc 1989; 21(Suppl): 26.

29 Nebelsick-Gullett LJ, Housh TJ, Johnson GO, Bauge SM. A comparison between methods of measuring anaerobic work capacity. Ergonomics 1988; 31: 1413-19.

30 Vandewalle $H$, Pérès G, Monod H. Standard anaerobic exercise tests. Sports Med 1987; 4: 268-89.

31 Fox EL, Bowers RW, Foss ML. The Physiological Basis of Physical Education and Athletics, 4th ed. Dubuque, Iowa, USA: Wm C Brown, 1988; 384. 